\title{
Maciej Jakub Zieliński, „Otwarte fundusze emerytalne jako wykonawcy ubezpieczenia społecznego w świetle swobody przepływu kapitału i swobody świadczenia usług w Unii Europejskiej”
}

Wydawnictwo C.H. Beck, Warszawa 2016, ISBN 978-83-255-8577-8, ss. 261.

Maciej Jakub Zieliński, „Open pension funds as economic actors of social security in a context of freedom of movement of capital and freedom to provide services in the European Union”, Publisher: C.H. Beck, Warsaw 2016, ISBN 978-83-255-8577-8, pp. 261.

Streszczenie. Artykuł recenzyjny analizuje i ocenia opracowanie monograficzne pt. „Otwarte fundusze emerytalne jako wykonawcy ubezpieczenia społecznego w świetle swobody przepływu kapitału i swobody świadczenia usług w Unii Europejskiej”. 
Słowa kluczowe: ubezpieczenia społeczne; otwarte fundusze emerytalne; Unia Europejska.

\begin{abstract}
This review provides an analysis and an evaluation of the monograph „Open pension funds as economic actors of social security in a context of freedom of movement of capital and freedom to provide services in the European Union”.
\end{abstract}

Keywords: social insurance; open pension funds; the European Union.

Otwarte fundusze emerytalne to istotny element II filara ubezpieczenia emerytalnego. Poświęcono temu podmiotowi w literaturze dużo miejsca, jednakże recenzowana książka jest pierwszym opracowaniem monograficznym, w którym autor skupił się na problematyce dotyczącej przepisów o swobodnym przepływie kapitału i usług.

Celem opracowania Macieja Jakuba Zielińskiego jest ustalenie, czy prawnie dopuszczalnie było powierzenie wykonywania ubezpieczeń społecznych otwartym funduszom emerytalnym, a jeśli tak, to czy do tych podmiotów mają zastosowanie przepisy o swobodnym przepływie kapitału i usług.

Praca została podzielona na III części, w ramach których występują rozdziały. Co do zasady konstrukcja pracy jest logiczna, prawidłowa, z jednym wyjątkiem - otóż ostatni (IV) rozdział pierwszej części pt. Konkretyzacja przedmiotu badań i założenia metodologiczne (s. 81-85) jest moim zdaniem zbędny. Treści w nim zawarte powinny być umieszczone we wstępie (autor wybrał formułę „Przedmowy”). Po części zresztą w rozdziale tym zostały powtórzone fragmenty umieszczone w „Przedmowie”, jak choćby te dotyczące celu pracy czy metod badawczych.

Pierwszy rozdział poświęcony został, słusznie zresztą, zagadnieniom podstawowym (wstępnym) dotyczącym wykonywania zadań z zakresu ubezpieczenia emerytalnego przez otwarte fundusze emerytalne. Autor rozpoczął swoje analizy od próby zdefiniowania pojęcia „zabezpieczenie 
społeczne” na płaszczyźnie prawnej ${ }^{1}$. Istotne, że M.J. Zieliński odniósł się nie tylko do art. 67 Konstytucji RP czy poglądów doktryny, ale sięgnął także do niezwykle istotnej konwencji nr 102 Międzynarodowej Organizacji Pracy. W dalszej kolejności przeanalizował ubezpieczenie emerytalne jako element składowy ubezpieczeń społecznych, a na uwagę zasługuje zaobserwowany przez autora problem braku precyzyjnego rozróżnienia w literaturze pomiędzy zasadami a cechami ubezpieczeń społecznych. Za potrzebne uznać należy krótkie przedstawienie ewolucji konstrukcyjnych elementów II filara oraz zarysowanie problematyki terminologicznej wykonawców ubezpieczeń społecznych.

W II rozdziale autor przedstawił ujęcie konstytucyjne wykonywania ubezpieczenia emerytalnego przez otwarte fundusze emerytalne. Zanim przedstawił swoje stanowisko, w sposób rzetelny wskazał na dotychczasowe ustalenia doktryny. Z racji tego, że wiele aspektów działalności otwartych funduszy emerytalnych budziło i wciąż budzi dużo wątpliwości, w literaturze w zakresie kluczowych kwestii występują nierzadko sprzeczne stanowiska. Cenne, że autor przedstawiając „za” i „przeciw” potrafił sensownie uargumentować swoje zdanie. Należy podkreślić, że omawiając zagadnienia dotyczące konstytucyjności nowelizacji ustaw regulujących system emerytalny w zakresie zmiany wysokości odprowadzanej składki do otwartych funduszy emerytalnych czy w zakresie przekazania części środków z OFE do FUS, autor unikał ocen o charakterze politycznym, skupiając się wyłącznie na argumentacji o charakterze prawnym.

Sporo miejsca autor poświęcił charakterowi prawnemu drugofilarowej składki emerytalnej. W literaturze i przestrzeni publicznej przez wiele lat toczyły się spory, czy ma ona charakter prywatnoprawny, czy publicz-

1 Bardzo obszerne analizy w tym zakresie przeprowadzono w monografii: K. Ślebzak, Prawo do zabezpieczenia społecznego w Konstytucji RP. Zagadnienia podstawowe, Warszawa 2015; w wielu innych opracowaniach próby wyjaśniania pojęcia „zabezpieczenie społeczne” były przeprowadzone w ograniczonym zakresie, jako wstęp do właściwych rozważań, np. J. Wantoch-Rekowski, System ubezpieczeń społecznych a budżet państwa. Studium prawnofinansowe, Warszawa 2014, s. 19-46 czy J. Wantoch-Rekowski, Składki na ubezpieczenie emerytalne: konstrukcja i charakter prawny, Toruń 2005, s. 17-27. 
noprawny. Wydaje się, że ostateczne rozstrzygnął to Trybunał Konstytucyjny w wyroku z 4 listopada 2015 r., który został szczegółowo przeanalizowany (s. 60 i n.). Nie zgadzam się jednak ze stwierdzeniem autora, że „uzasadniona wydaje się teza, że dotychczasowy model filara kapitałowego mógł być uznany za realnie zagrażający zachowaniu równowagi budżetowej”. Problem bowiem w tym, że składki drugofilarowe, owszem, przyczyniały się do konieczności przekazywania środków z budżetu państwa do Funduszu Ubezpieczeń Społecznych w celu zapewnienia ciągłości wypłaty świadczeń, ale było to zjawisko, które zostało zdiagnozowane w trakcie prac nad przygotowaniem reformy, którą ostatecznie wdrożono 1 stycznia 1999 r. Koszty reformy zostały oszacowane i wskazano na źródła ich sfinansowania (głównie na środki z prywatyzacji majątku Skarbu Państwa). Trudno więc uzasadniać zmiany w funkcjonowaniu otwartych funduszy emerytalnych tym, że nagle okazało się, że równowaga budżetowa jest zagrożona, czego wcześniej przewidzieć nie można było. Przewidywano to i zaproponowano rozwiązania prawne jako antidotum na to niekorzystne zjawisko. Okazało się jednak, przy braku możliwości realnego zwiększania dochodów budżetowych, że w praktyce możliwe było albo zwiększenie deficytu budżetowego, albo ograniczenie pewnej kategorii wydatków. Znacznie zmniejszając wpływy do otwartych funduszy emerytalnych, a tym samym dotację budżetową, umożliwiono dokonywanie innych wydatków za „zaoszczędzone” środki, głównie o charakterze socjalnym.

Z uwagi na tematykę recenzowanej monografii niezbędne było przedstawienie zagadnień ogólnych dotyczących zabezpieczenia społecznego w kontekście Unii Europejskiej. Autor syntetycznie i przejrzyście przedstawił takie kluczowe zagadnienia, jak zabezpieczenie społeczne jako przedmiot regulacji prawa Unii Europejskiej oraz stosowanie przepisów dotyczących swobód rynku wewnętrznego Unii Europejskiej w dziedzinie zabezpieczenia społecznego.

Część II opracowania została poświęcona swobodzie wyboru przez ustawodawcę zwykłego wykonawców zabezpieczenia emerytalnego. W rozdziale I autor analizował uwarunkowania prawne wyznaczające granice swobody w zakresie wyboru wykonawców ubezpieczenia emery- 
talnego. Rozważania swoje oparł na przepisach Konstytucji RP, regulacjach prawa międzynarodowego, regulacjach Rady Europy i przepisach Unii Europejskiej. Rozdział ten kończy się „Wnioskami”. Autor sformułował trzy zasadnicze: 1) analiza art. 67 prowadzi do ustaleń, że zakres przysługującej ustawodawcy swobody wyboru wykonawców zabezpieczenia społecznego w Polsce jest stosunkowo szeroki, 2) swoboda ustawodawcy krajowego w zakresie wyboru wykonawców nie jest niczym nieograniczona, a najważniejsze ograniczenia wynikają z regulacji Międzynarodowej Organizacji Pracy, 3) na płaszczyźnie przepisów unijnych określanie wykonawców poszczególnych rodzajów zabezpieczenia pozostaje w wyłącznej kompetencji państw członkowskich, jednak muszą one respektować podstawowe zasady prawa unijnego. Wnioski przedstawione przez autora uznać należy za poprawne. Z kolei w rozdziale II zawarto interesujące analizy dotyczące formy organizacyjno-prawnej OFE, przedmiotu działalności OFE oraz terytorialnych i podmiotowych ograniczeń prowadzenia przez te podmioty działalności. Koniecznym było także przedstawienie zagadnień dotyczących nadzoru nad działalnością OFE, co autor uczynił. Również ten rozdział kończy podsumowanie; warto przytoczyć jego ostatni akapit: „Powyższe wnioski otwierają możliwość podjęcia rozważań na temat tego, czy, a jeżeli tak, to w jakim zakresie, do OFE jako podmiotów niepublicznych mogą znajdować zastosowanie przepisy Traktatu o Funkcjonowaniu Unii Europejskiej dotyczące swobodnego przepływu usług i kapitału, tym bardziej że kwestia dotycząca tej ostatniej swobody była przedmiotem wypowiedzi doktryny oraz orzecznictwa Trybunału Sprawiedliwości Unii Europejskiej” (s. 159).

Ostatnia część monografii poświęcona została już „właściwym” zagadnieniom, tj. działalności OFE z punktu widzenia swobody przepływu kapitału i przepływu usług w ramach rynku wewnętrznego Unii Europejskiej. Ten fragment został podzielony na dwa rozdziały. W I autor podjął udaną próbę analizy działalności OFE w kontekście swobody przepływu kapitału. Słusznie rozpoczął od przedstawienia kluczowych pojęć (swoboda przepływu kapitału, rynek wewnętrzny etc.). Analizując pojęcie przepływu kapitału, zwrócił uwagę, że prawodawca traktatowy nie zdefiniował go, pozostawiając ustalenie jego znaczenia orzecznictwu. W roz- 
dziale I nieodzowne było także - co autor poprawnie uczynił - przedstawienie: kryterium „transnacjonalności” jako kryterium stosowania przepisów o swobodzie przepływu kapitału oraz pojęcia ograniczeń swobody przepływu kapitału i ich dopuszczalności. Sporo miejsca zostało poświęcone analizie art. 106 ust. 2 TFUE, co jest zasadne, gdyż z perspektywy tematyki badań zawarte jest $\mathrm{w}$ tym przepisie istotne ograniczenie zastosowania przepisów o swobodzie przepływu kapitału (s. 176 i n.). Bardzo wysoko należy ocenić ten fragment monografii (s. 186-212), w którym autor $\mathrm{z}$ różnych perspektyw przeanalizował wyrok $\mathrm{W}$ sprawie C-271/09 i wskazał na jego skutki w dziedzinie stosowania zasady swobody przepływu kapitału. Rozdział kończy się wnioskami. Na szczególną uwagę zasługuje wniosek nr 8 - wg autora argumentacja strony polskiej w czasie postępowania przed TSUE w sprawie C-271/09 niesłusznie koncentrowała się na kwestii dopuszczalności oceny z perspektywy art. 63 TFUE, a powinna powoływać się na wyłączenie zastosowania w odniesieniu do OFE traktatowej zasady przepływu kapitału (art. 106 ust. 2 TFUE).

Skoro rozdział I dotyczył zagadnień związanych ze swobodą przepływu kapitału, to - aby zachować konsekwencję - w rozdziale II zawarto analizy dotyczące działalności OFE w kontekście swobody przepływu usług. Autor na wstępie „tłumaczy”, że wprawdzie pozornie mogłoby się wydawać, że zastosowanie przepisów dotyczących swobodnego przepływu usług w dziedzinie zabezpieczenia społecznego jest znikome, ale w praktyce ważne znaczenie mogą mieć aspekty związane z bierną swobodą przepływu usług. Na szczególną uwagę zasługuje ten fragment rozdziału, w którym autor analizuje możliwość stosowania przepisów o swobodnym przepływie usług do działalności OFE (s. 213 i n.). Całość kończą ciekawe wnioski.

W „Podsumowaniu” autor wskazał, że „Przeprowadzone rozważania doprowadziły do wniosku, że na gruncie Konstytucji RP, wiążących Polskę aktów prawnych Rady Europy ustawodawca zwykły mógł powierzyć OFE wykonywanie zabezpieczenia społecznego na wypadek osiągnięcia wieku emerytalnego (...) Jeśli chodzi zaś o perspektywę prawa Unii Europejskiej, to OFE mogą być kwalifikowane jako przedsiębiorstwa zobo- 
wiązane do zarządzania usługami świadczonymi w ogólnym interesie gospodarczym, co, z mocy art. 106 ust. 2 TFUE, może oznaczać, że nie podlegają przepisom o swobodnym przepływu kapitału i usług” (s. 253). Autor wskazał także na główne tezy opracowania (siedemnaście) - są one niewątpliwie interesujące i wartościowe.

Za prawidłowy uznać należy wybór metod badawczych - przede wszystkim autor wykorzystał metodę dogmatyczno-prawną, a uzupełniająco metodę historyczno-porównawczą. Na uznanie i podkreślenie zasługuje „rozmach” w zakresie wykorzystanej literatury (w tym zagranicznej) i orzecznictwa.

Bez względu na to, jakie będą losy otwartych funduszy emerytalnych, recenzowana monografia jest pozycją bardzo wartościową, w sposób obszerny analizującą problematykę emerytalną z perspektywy przepisów o swobodnym przepływie kapitału i usług.

\section{Bibliografia:}

Ślebzak K., Prawo do zabezpieczenia społecznego w Konstytucji RP. Zagadnienia podstawowe, C.H. Beck, Warszawa 2015.

Wantoch-Rekowski J., Składki na ubezpieczenie emerytalne: konstrukcja i charakter prawny, TNOiK, Toruń 2005.

Wantoch-Rekowski J., System ubezpieczeń społecznych a budżet państwa. Studium prawnofinansowe, Lex a Wolters Kluwer business, Warszawa 2014. 